\title{
Leaf litter decomposition from native and non-native species in a freshwater forested wetland of Chile
}

\section{Descomposición de hojarasca de especies nativas y exóticas en un humedal boscoso de agua dulce de Chile}

\author{
Francisco Gómez-Capponi ${ }^{1,3}$, Francisco Correa-Araneda ${ }^{1,2, *}$, M $^{a}$ Elisa Diaz ${ }^{1}$, Manuel Olguín 5 , \\ Francisco Encina-Montoya ${ }^{4} \&$ Ricardo Figueroa ${ }^{1}$ \\ ${ }^{1}$ Water Quality Bioindicators Laboratory, Faculty of Environmental Sciences, University of Concepción, P.O. Box 160-C, \\ Concepción, Chile. \\ ${ }^{2}$ Department of Zoology, Faculty of Natural and Oceanographic Sciences, University of Concepción, P.O. Box 160-C, \\ Concepción, Chile. \\ ${ }^{3}$ Institute of Environmental Sciences and Evolution, Science Faculty, Austral University of Chile, Valdivia, Chile. \\ ${ }^{4}$ Ecotoxicology and Environmental Monitoring Laboratory, Environmental Sciences School, Faculty of Natural Resources, \\ Catholic University of Temuco, P.O. Box 15-D, Temuco, Chile. \\ ${ }^{5}$ Environmental Department, Aquaculture Research Division, Fisheries Development Institute, Puerto Montt, Chile. \\ *franciscocorrea@udec.cl
}

\begin{abstract}
Decomposition of leaf litter is a fundamental process for the functioning of forested wetlands. The rapid increment of forest plantations has involved a greater contribution of leaf litter of exotic origin to these ecosystems. The decomposition rate between leaf litter of native and exotic origin in a forested wetland of the Mediterranean zone of Chile was compared, as well as the contribution of bacteria and macroinvertebrate to this process. It was determined that the decomposition rate of the leaf litter presented significant differences $(p<0.05)$ between species, being faster in those of non-native origin. This could be due to differences in ecophysiological aspects of the leaves like the presence of chemical compounds such as waxes or oils. Both analyzed communities were relevant in the studied process. However, bacteria contributed mostly to the decomposition of both types of leaves. The implications of the physical and chemical characteristics of the leaves and the water on the processing of the foliar material are discussed.
\end{abstract}

KEYwORDs: Allochthonous detritus, bacteria, lentic ecosystem, macroinvertebrates.

\section{RESUMEN}

En los humedales boscosos, la descomposición de la hojarasca es un proceso fundamental para su funcionamiento. El rápido incremento de las plantaciones forestales ha implicado un mayor aporte de hojarasca de origen exótico a estos ecosistemas. Se comparó la tasa de descomposición entre hojarasca de origen nativo y exótico en un humedal boscoso de la zona Mediterránea de Chile, así como la contribución de las bacterias y macroinvertebrados a este proceso. Se determinó que la tasa de descomposición de la hojarasca presentó diferencias significativas entre las diferentes especies $(\mathrm{p}<0,05)$, siendo más rápido en especies de origen exótico. Esto podría ser dado por diferencias en algunos aspectos ecofisiológicos de las hojas como la presencia de compuestos químicos tales como ceras o aceites. Ambas comunidades analizadas fueron relevantes en el proceso estudiado. Sin embargo, las bacterias contribuyeron mayormente a la descomposición de ambos tipos de hojas. Se discuten las implicaciones de las características físicas y químicas de las hojas y el agua en el procesamiento del material foliar.

Palabras clave: Detritus alóctono, bacterias, ecosistema léntico, macroinvertebrados.

\section{INTRODUCTION}

In Chile, forested wetlands show a wide distribution $\left(29^{\circ} \mathrm{S}\right.$ $\left.-42^{\circ} \mathrm{S}\right)$, though they mostly dominate in the Mediterranean zone (MZ) $\left(33^{\circ} \mathrm{S}-39^{\circ} \mathrm{S}\right)$. In that zone, most wetlands show some degree of human intervention (e.g. urbanization, wood extraction and introduction of exotic species) (CorreaAraneda et al. 2011), which has led to their fragmentation, eutrophication and reduced ecosystem services. Arboreal vegetation of these ecosystems is fundamental for their 
functioning, because it causes a low penetration of light, limiting the primary activity of phytoplankton (Benfield 1996) and it implies that their main source of organic matter is the material coming from the woody component (e.g. leaves, twigs, flowers and fruits) (Correa-Araneda et al. 2011). This material has been mainly supplied by hydrophilic native species from the Myrtaceae family, such as Blepharocalyx cruckshanksii (Hook. \& Arn.) Nied and Myrceugenia exsucca (DC) Berg (Correa-Araneda et al. 2012). However, in the last four decades they have been replaced by exotic species, mainly Pinus radiata (D. Don) and Eucalyptus globulus (Labill), which have been steadily increased in the Chilean Mediterranean Zone (ChMZ) (Shulz et al. 2010, 2011; CONAF 2011). For these species, an increase of up to $53 \%$ in the period $1975-2000$ has been registered, with an annual growth that reached 10.5\% (Pizarro et al. 2006; Little et al. 2009) and currently representing more than $17 \%$ of the forest area of the country (CONAF 2011).

The replacement of native vegetation of the ChMZ by monocultures of exotic species could be influencing the processes that regulate flows of matter and energy to and within the system, as reported in lotic systems (Canhoto \& Graça 1995; Canhoto et al. 2013). One of the processes involved in the energy flows in the wetlands corresponds to the degradation of the leaf litter and includes several trophic levels (Solada et al. 1996). This process starts with the release of soluble compounds (Solada et al. 1996), followed by a colonization of bacteria and fungi (BF) that facilitates the subsequent fragmentation and consumption by benthic macroinvertebrates (BMI) (Abelho 2001; Weyers \& Suberkropp 1996; Gessner et al. 1998). This indicates that both communities (BF and BMI) play a critical role in maintaining the flows of matter and energy (Sylvestre \& Bailey 2005; Boyero et al. 2011).

Recent studies have determined that the decomposition of the leaf litter in freshwater ecosystems is influenced for both environmental variables (e.g. $\mathrm{pH}$, temperature, water regime) and structural components of the leaf itself, such as lignin, cellulose, cutin and tannins (Richardson et al. 2004; Swan \& Palmer 2004; Graça \& Cressa 2010). That is why any change in the type of vegetation that is incorporated into the water component of the forested wetlands would impact significantly on the functioning of the system, affecting the capacity of processing this material (Graça \& Canhoto 2006). However, the mechanisms are not entirely clear, since wetlands have been very poorly studied (Correa-Araneda et al. 2011). Because of the abovementioned backgrounds, the present study is aimed to evaluate the degradation process of the leaf litter carried out by the communities of BF and $\mathrm{BMI}$ on the foliar component of native and non-native plants from the forested wetlands.

\section{MATERIAL AND METHODS}

STUDY AREA

The study area was located at the Petrenco forested wetland (3902'35" S - 72³8'54" W) (Fig. 1). This wetland belongs to the Blepharocalyo-Myrceugenietum exsuccae (temupitra) vegetation association (Ramírez et al. 1995) which presents a permanent water regime, with depths that vary between 31 and $70 \mathrm{~cm}$. The climate in the area corresponds to Mediterranean with oceanic influence and presents an annual temperature and rainfall of $12^{\circ} \mathrm{C}$ and $1,553 \mathrm{~mm}$, respectively (Di Castri \& Hajek 1976).

\section{EXPERIMENTAL DESIGN}

In order to evaluate the degradation process of foliar material, we used: leaves coming from the species Blepharocalyx cruckshanksii (Temu), Myrceugenia exsucca (Pitra), dominant native species in the wetland (Ramírez et al. 1995); Pinus radiata and Eucalyptus globulus, dominant exotic species in the ChMZ (CONAF 2011). The mixture of leaf litter from these species was also studied. The foliar material was collected by means of leave traps and dried at $60^{\circ} \mathrm{C}$ (Memmert ULM-600 oven) for 24 hours until constant weight was obtained. Groups of leaves were formed with a standardized weight of $3 \pm 0.1 \mathrm{~g}$, determined through a digital scale (Precisa 240; $0.0001 \mathrm{~g}$ sensitivity).

The treatments used in the experiments were as follows: temu (T), pitra (Pit), eucalyptus (E), pine (Pin), temupitra (TPit) and pine-eucalyptus (PinE) $(n=4$ replicates per treatment). All samples were stored in containers $(20 \times 20$ $\mathrm{cm}$ ) with $1 \mathrm{~cm}$ pore opening (mesh, $\mathrm{n}=96$ ) for colonization by BMI. On the other hand, a pore opening of $55 \mu \mathrm{m}$ (bags, $n=96$ ) were used to allow colonization only by BF. All replicas were submerged and randomly distributed throughout the wetland.

The experiment lasted 60 days and the decomposition of the leaf litter was measured at 15 day intervals during the autumn season of 2011. In each collection period, 4 replicates per treatment and type of containers were collected.

Extracted samples were washed (in order to eliminate the accumulated sediment), dried and weighted, according to the initial described treatment. For the calculation of the degradation of total leaf litter $(\mathrm{k})$ the negative exponential model was used (Hladyz et al. 2010): $\mathrm{W}_{\mathrm{t}}=\mathrm{W}_{\mathrm{i}} \mathrm{e}^{-\mathrm{kt}}$, where $\mathrm{t}$ corresponds to time, $\mathrm{W}_{\mathrm{t}}$ corresponds to the dry weight at $\mathrm{t}$ time measured in percentage respect to initial weight, $\mathrm{W}_{\mathrm{i}}$ is the initial dry mass of the leave fixed in $100 \%$ and $\mathrm{k}\left(\right.$ days $^{-}{ }^{-}$) is the slope of the plot of the natural logarithm of the mass of the leave in relation to time, and it corresponds to the only decomposition rate that allows performing the comparative analyses.

In order to have a complementary measure of the foliar material degradation, the toughness of the leaves of each 
species was determined in each sampling period using a Leaf Toughness Tester (Woodcock \& Huryn 2005). This was conducted on 5 leaves or fragments randomly selected from the replicas of each treatment. Results were expressed in penetrance $(\mathrm{g})$ that corresponds to the minimum strength applied on a surface of $0.29 \mathrm{~mm}^{2}$, necessary to penetrate the leaf.

In order to determine the physicochemical characteristics of the water column, temperature $\left({ }^{\circ} \mathrm{C}\right), \mathrm{pH}$, conductivity $(\mu \mathrm{S}$ $\left.\mathrm{cm}^{-1}\right)$, turbidity (NTU) and dissolved oxygen $\left(\mathrm{mg} \mathrm{L}^{-1}\right)$ were measured in each period, using a YSI-30 sensor (Wetzel \& Likens 1991).

\section{STATISTICAL ANALYSES}

After verifying the normality of data in order to evaluate the individual effect and the interactions of the factors on the quantitative dependent variable, a covariance analysis was carried out (ANCOVA).The quantitative independent variables were: colonizing community (BF and BF-BMI) and treatment (T, Pit, E, Pin, TPit and EPin). The covariable was exposure time $(15,30,45$ and 60 days), whereas the dependent variable was the degradation rate (amount of mass lost over time). All analyses were performed with the following software: Statistica 7 (StatSoft Inc. 2004) y PASTPalaeontological Statistics 2.10 (Hammer et al. 2001).

\section{RESULTS}

The degradation of the foliar detritus was faster in the treatments with non-native species (Pin, E) in comparison to native species (T, Pit) (Fig. 2a, 2b). Leaves of E. globulus presented the highest degradation rate, leaving $61.9 \%$ of the leaves exposed to $\mathrm{BF}$ and $58.8 \%$ of the leaves exposed to $\mathrm{BF}$ and BMI at the end of the exposure period ( 60 days). The lowest degradation rate among native species was presented

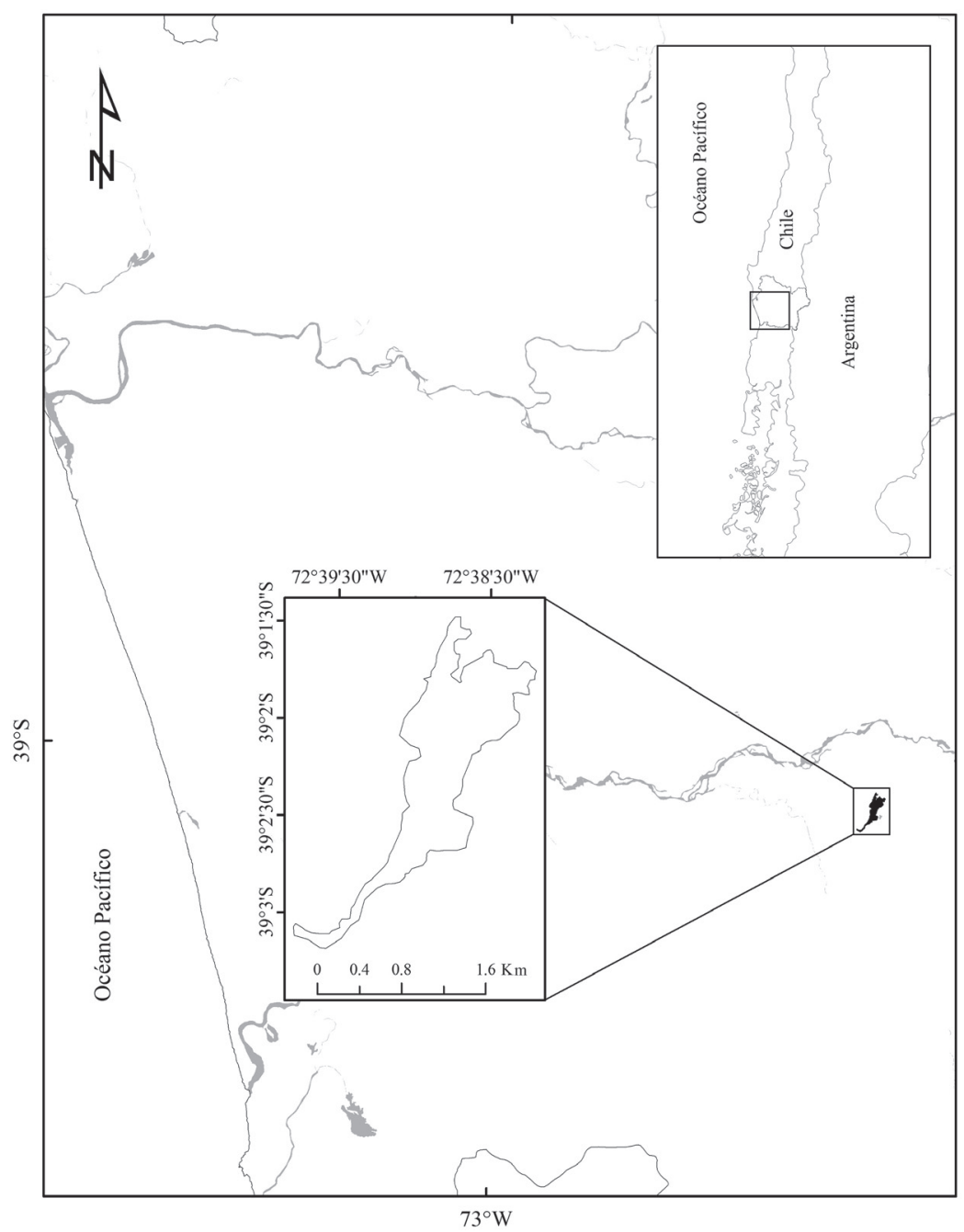

FiguRE 1. Location of the study area corresponding at the wetland Petrenco located in the commune of Pitrufquén, Araucanía Region, Chile. / Ubicación del área de estudio correspondiente al humedal Petrenco de la comuna de Pitrufquén, región De la Araucanía, Chile. 
by Temu (B. cruckshanksii), where $86.9 \%$ of the leaves exposed to BF remained and $79.6 \%$ of the leaves exposed to BF and BMI. The greatest degradation of leaf litter was registered during the first 15 days for both non-native and native species (Fig. 2c, 2d).

Covariance analyses (ANCOVA) for the degraded plant species indicates that there are statistically significant differences $(p<0.05)$ between the exposure to BF and BF$\mathrm{BMI}$, as well as between types of leaf litter, but there is no co-variation between the types of tree of came from and the exposure of the different communities (Table 1).

Regarding the toughness of the leaves, the average of the initial toughness of the experiment was $387 \mathrm{~g}$ in $M$. exsucca, $219 \mathrm{~g}$ in B. cruckshanksii, $251 \mathrm{~g}$ in E.globulus and $293 \mathrm{~g}$ in $P$. radiata. No clear pattern of increase or decrease over time was observed (Fig. 3). Indeed, this pattern tended to maintain constant, without significant differences $(p>0.05)$.

TABLE 1. ANCOVA analysis from the variables of time (covariate), type of container and type of leaves respect to degradation rate. / Análisis de ANCOVA de las variables de tiempo (covariable), tipo de contenedor y tipo de hoja respecto a la tasa de descomposición.

\begin{tabular}{lcccc}
\hline & g.l. & MS & F & $p$ \\
\hline Time & 3 & 0.003 & 232.1 & $0.001 *$ \\
Container & 1 & 0 & 005.3 & $0.022^{*}$ \\
Fallen leaves & 5 & 0.001 & 052.5 & $0.001 *$ \\
Container - fallen leaves & 5 & 0 & 1.1 & 0.364 \\
\hline
\end{tabular}
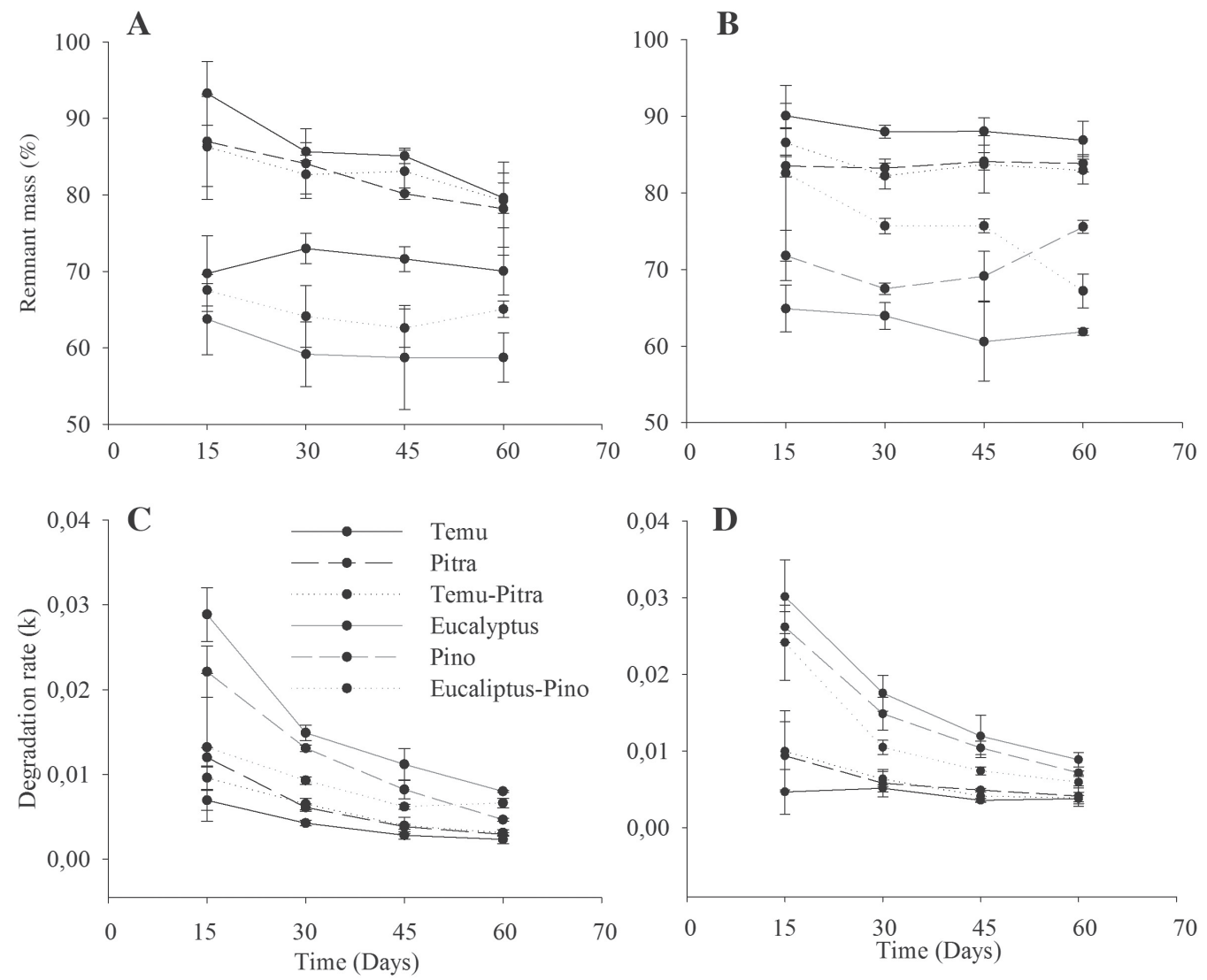

FIGURE 2. Temporal variation of remnant mass rate of the different species exposed to colonization by BF (A) and BF-BMI (B), and the degradation rate of the different species exposed to colonization by BF (C) and BF-BMI (D) during their 60 day exposure in the water column. / Variación temporal de la masa remanente de las diferentes especies expuestas a la colonización por BF (A) y BF-BMI (B) y tasa de degradación de las diferentes especies expuestas a la colonización por BF (C) y BF-BMI (D) durante los 60 días de exposición en la columna de agua. 
However, this variable did presented significant differences between type of leaves (native- exotic) ( $p=$ 0.002). The Tuckey HSD test for toughness indicated that the differences between types of leaves are mostly given by the leaves of exotic origin, specifically of the species $E$. globulus (EPit vs EPin, $p<0.05$ ).

Physicochemical variables measured in the water column presented a strong direct correlation between conductivity, dissolved oxygen and turbidity, as well as between temperature and $\mathrm{pH}$. Only turbidity showed a clear trend to decrease at temporal scale $\left(\mathrm{T}_{0}=75.2 \mathrm{NTU}-\mathrm{T}_{1}=1.8\right.$ NTU). However, all variables presented a high dispersion respect to their mean value (C.V. $>0.05)$ (Table 2) all the variables with correlation, show significant differences $(p<$ 0.05 ) less the correlation between turbidity and O.D.

TABLE 2. Values of the physicochemical variables of the water column in the different sampling days, Coefficient of variation (CV) and correlation analyses between variables. Cond. $=$ Conductivity $(\mu \mathrm{S} / \mathrm{cm})$, Temp. $=$ Temperature $\left({ }^{\circ} \mathrm{C}\right)$, O.D. $=$ Dissolved oxygen $\left(\mathrm{mg} \mathrm{L}^{-1}\right)$, * = strong correlation. / Valores de las variables fisicoquímicas de la columna de agua en los diferentes días de muestreo, coeficiente de variación $(\mathrm{CV})$ y análisis de correlación entre las variables. Cond. $=$ Conductividad $(\mu \mathrm{S} / \mathrm{cm})$, Temp. $=$ Temperatura $\left({ }^{\circ} \mathrm{C}\right)$, O.D. $=$ Oxígeno disuelto $\left(\mathrm{mg} \mathrm{L}^{-1}\right), *=$ Correlación fuerte.

\begin{tabular}{|c|c|c|c|c|c|c|c|c|c|c|c|}
\hline & $\mathrm{T}_{0}$ & $\mathrm{~T}_{1}$ & $\mathrm{~T}_{2}$ & $\mathrm{~T}_{3}$ & $\mathrm{~T}_{4}$ & Mean & C.V. & Cond. & $\mathrm{pH}$ & Temp. & O.D. \\
\hline Cond. & 54.4 & 36 & 30 & 27.8 & 39.9 & $37.6 \pm 9.4$ & 0.28 & & & & \\
\hline $\mathrm{pH}$ & 6.18 & 6.32 & 6.29 & 5.13 & 6.6 & $6.1 \pm 0.5$ & 0.09 & 0.18 & & & \\
\hline Temp. & 8 & 9.25 & 7.45 & 5.9 & 9.3 & $7.7 \pm 1.4$ & 0.17 & 0.19 & $0.80^{*}$ & & \\
\hline O.D. & 3.9 & 5.8 & 7.9 & 7.3 & 6.1 & $6.2 \pm 1.4$ & 0.24 & $0.90^{*}$ & 0.09 & 0.20 & \\
\hline Turbidity & 75.2 & 1.73 & 3.55 & 2.4 & 1.8 & $16.9 \pm 29.1$ & 1.92 & $0.78^{*}$ & 0.01 & 0.00 & $0.67 *$ \\
\hline
\end{tabular}
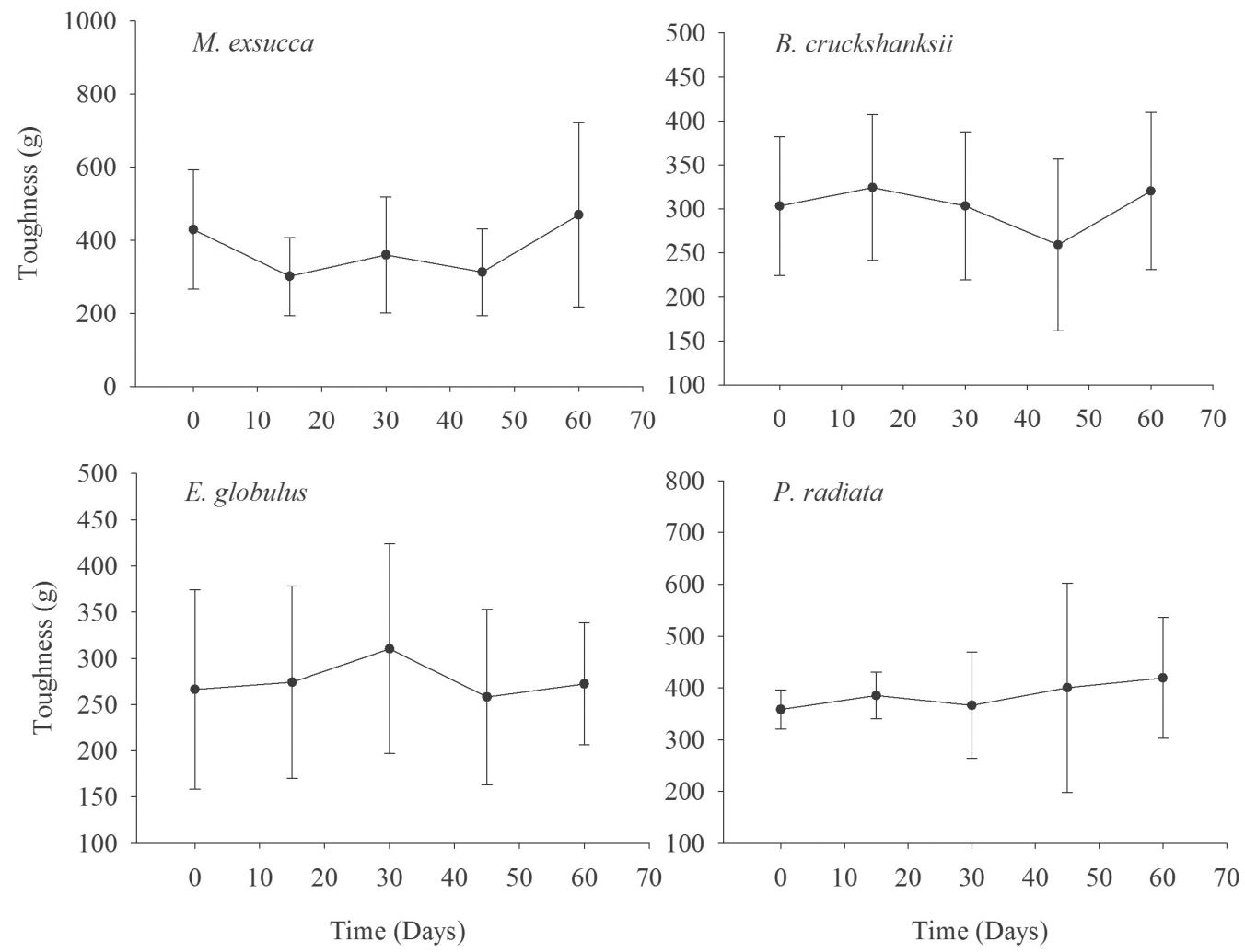

FIGURE 3. Temporal variation of the toughness (g) in the leaves of native (M. exsucca and B. cruckshanksii) and non-native species (E. globulus and P. radiata). / Variación temporal de la dureza (g) en las hojas de especies nativas (M. exsucca and B. cruckshanksii) y exóticas (E. globulus and P. radiata). 


\section{DISCUSSION}

The general phases of the degradation of the foliar material in aquatic ecosystems have been described as sequential, initiated by a lixiviation process of the soluble compounds, followed by a colonization of BF which facilitates the arrival of the BMI, especially shredders (Cheshire et al. 2005). Our results showed that the greatest weight loss was registered during the first 15 days for both native and exotic species. This coincides with liberation phase of soluble compounds, described as the phase of greater weight loss in the foliar material (Solada et al. 1996).

In the heads of the mountain lotic environments like in the wetlands, light penetration is scarce and they receive a high load of fallen leaves (Lugo et al. 1990), and the decomposition process is mainly given by BMI (Vannote et al. 1980). In forested wetlands BMI would also be a determinant factor in the processing of organic matter, because in containers with presence of these organisms together with communities of bacteria and fungi (BF) was observed a significantly higher decomposition than in the case where only BF were present. This is in agreement with what was reported in tropical forested wetlands by Del Valle (2003), where the macroinvertebrate community was also relevant in the processing of organic matter. However, forested wetlands present important differences respect to mountain river environments, as well as in other lentic environments (e.g. freshwater marshes and exposed lagoons), both in physical, chemical and biological characteristics. The fact that there is no mechanical effect produced by the water movement and the benthic components must be highlighted (Casas et al. 2000), because this would explain the high nondegraded percentage of organic material in these ecosystems. This implies that the total degradation of the plant material would last twice the time considered for the current study or even more. It is interesting to mention that the shredding organisms not showed preference by native or non-native leaf litter, so that differences registered in the decomposition rate were mostly influenced by species-specific features. This is the case of the toughness of the leaves which in native species was higher compared to exotic species, as reported by Ramírez et al. (1980), who indicated that these species have a leathery nature. In addition, none of the species presented significant differences in toughness at timescale, contrary to was observed in mountain river environments from the $\mathrm{ChMZ}$, where these were negatively correlated to the exposure time (Ovalle 2012). In the latter case, the mechanical effect that takes place in these environments was a determinant factor on the variations of the toughness of leaves. The presence of chemical compounds such as waxes or oils secreted by the leaves, described for B. cruckshanksii (Tucker et al. 1993), would provide hydrophobicity to the leaf, affecting the capacity of the BF community to penetrate the tissue. This implies that the decomposition process by these microorganisms is dependent on the individual features of each leaf.

An interesting case about the interaction between BF, BMI and the physicochemical characteristics of the leaves is presented by the species E. globulus, which has phenolic compounds whose anaerobic degradation can initiate an increment in compounds such as quinones, which are highly toxic for BMI from aerobic systems. This would not occur equally in forested wetlands, given the low concentration of oxygen registered (Canhoto et al. 2013). but compounds like quinones not be affecting the bacterial degradation, causing that forested wetlands eucalyptus are degraded faster than native species. Hence, under these conditions the $\mathrm{BF}$ community would be more relevant on the degradation of organic matter of forested wetlands in comparison to BMI. Another variable that can affect the degradation rate, though not assessed in the present study is the surface are of the leaves, which can be affecting the size of fungi colonies associated to the degradation of organic matter (Allen et al. 1991). It would be interesting to incorporate this issue in further studies.

In most aquatic ecosystems, physicochemical variables such as temperature, conductivity, amount of dissolved oxygen and nutrients are fundamental to the development of the organisms (Haapala et al. 2001). In this regard, the environmental variables measured in the water column presented timescale variations, as well as direct relations between conductivity, dissolved oxygen and turbidity; this would be associated to the rainfall events that decrease turbidity and the concentration of ionic compounds responsible for the conductivity (Arle 2002). This is an indicator of the buffer effect that would be produced by the forest cover, intercepting the water to enter the system by means of streamflow, which decreases the contribution and resuspension of fine sediments (McIvor et al. 2012), implying a lower perturbation of the water column (FAO 2005).

Dissolved oxygen is one of the most relevant variables for aquatic life. This level was registered in low concentrations in the forested wetlands $\left(6.2 \pm 1.38 \mathrm{mg} \mathrm{L}^{-1}\right)$, in comparison to that observed in aquatic environments of the same area (8.7 - $11.6 \mathrm{mg} \mathrm{L}^{-1}$; Habit et al. 2003; Figueroa et al. 2003; Correa-Araneda et al. 2010, 2014), which implies the dominance of resident and generalist organism, such as the BF community (Bärlocher \& Kendrick 1974; Figueroa et al. 2003). Such organisms would be the main responsible of the degradation and changes in the toughness of the fallen trees in this kind of aquatic ecosystems.

Regarding the temperature, this variable affects the dissolution of oxygen in the water (Alvarado \& Aguilar 2009), the metabolism of the organisms and many other factors are directly or indirectly related to the processing of organic matter (Hauer \& Hill 2007). The low temperatures recorded $\left(5.9-9.3^{\circ} \mathrm{C}\right)$, prevent the descent of the levels of oxygen to hypoxic levels and foster an ideal environment 
to the development of psychrophilic bacteria $\left(0-30^{\circ} \mathrm{C}\right)$ (Morita 1975), which have a slower reproduction rate respect to mesophilic or thermophilic bacteria (Elliot \& Michener 1965).

Forested wetlands present differential characteristics with other types of wetlands, highlighting the low penetration of light and explaining the low temperatures of the water, the constant supply of fallen leaves and the low degradation rate of organic matter. These features make forested wetlands particularly vulnerable against the excessive input of organic matter as a result of the diverse productive activities carried out in the area. In addition, the loss of forest material as a result of its extraction for human consumption (Correa-Araneda et al. 2011) can facilitate the input of light, generating changes in the thermal regime and in the related variables (Döll \& Zhang 2010). The synergistic effect of these modifications might lead to a greater bacterial colonization (Molinero et al. 1996), accelerating biological processes (Cortes 1992, Belovsky \& Slade 2000) and in turn, causing a greater consumption of oxygen. This would modify many of the physical and chemical characteristics of these ecosystems. These processes have not been yet clarified and the interest on them from a limnological point of view is emerging. Therefore, delving into these processes is of great importance to encourage and support future actions of both restoration and preservation.

\section{ACKNOWLEDGEMENTS}

The authors acknowledge a) FONDAP CRHIAM 1513001; b) Native Forest Research Found (035-2010) from the Chilean National Forest Corporation; c) Research Directorate of Catholic University of Temuco, Chile; d) MECESUP Project UCT 0804. Special thanks to Alberto Alvarez and $\mathrm{M}^{\mathrm{a}}$ Fernanda Aguayo for their field work and analysis of samples.

\section{REFERENCES}

Abelho, M. 2001. From litterfall to breakdown in streams: a review. The Scientific World Journal 1:656-680.

Allen, E.A., Hoch, H.C., Steadman, J.R., Stavely, R.J. 1991. Influence of leaf surface features on spore deposition and the epiphytic growth of phytopathogenic fungi. In: Microbial ecology of leaves (Eds. Andrews, J.H., Hirano, S.S.), pp. 87-110. Springer-Verlag. New York.

Alvarado, J., Aguilar, J.F. 2009. Batimetría, salinidad, temperatura y oxígeno disuelto en aguas del Parque Nacional Marino Ballena, Pacífico. Costa Rica. Revista de Biología Tropical 57(1):19-29.

Arle, J. 2002. Physical and chemical dynamics of temporary ponds on a calcareous plateau in Thuringia, Germany. Limnologica 32:83-101.

BÄRLOCHER, F., KENDRICK, B. 1974. Dynamics of the population on leaves in stream. Journal of Ecology 62:761-791.

Belovsky, G., Slade, J.B. 2000. Insect herbivory accelerates nutrient cycling and increases plant production. Proceedings of the National Academy of Sciences USA, 97(26):14412-14417.

BeNFIELD, E.F. 1996. Leaf breakdown in stream ecosystems. Methods in stream ecology. In: Hauer, F.R., Lamberti G.A. (ed.). Academic Press. London, United Kingdom, pp. 579-589.

Boyero, L., Pearson, R.G., Gessner, M.O., Barmuta, L.A., Ferreira, V., Graça, M.A.S., Dudgeon, D., Boulton, A.J., Callisto, M., Chauvet, E., Helson, J.E., Bruder, A., Albariño, R.J., Yule, C.M., Arunachalam, M., Davies, J.N., Figueroa, R., Flecker, A.S., Ramírez, A., Death, R.G., Iwata, T., Mathooko, J.M., Mathuriau, C., Gonçalves, J.F., Moretti, M.S., JingGut, T., Lamothe, S., Erimba, C.M., Ratnarajah, L., Schindler, M.H., Castela, J., Buria, L.M., Cornejo, A., Villanueva, V.D., West, D.C. 2011. A global experiment suggests climate warming will not accelerate litter decomposition in streams but might reduce carbon sequestration. Ecology Letter 14:289-294.

Canhoto, C., Graça, M.S. 1995. Food value of introduced eucalypt leaves for a Mediterranean stream detritivore: Tipulalateralis. Freshwater Biology 34(2):209-214.

Canhoto, C., Calapez, R., Goncalves, A.L., Moreira, M. 2013. Effects of Eucalyptus leachates and oxygen on leaf-litter processing by fungi and stream invertebrates. Freshwater Sciences 32(2):411-424.

Casas, J.J., Zamora-Muñoz, C., Archila, F., Alba-Tercedor, J. 2000. The effect of a headwater dam on the use of leaf bags by invertebrate communities. Regulated Rivers: Research \& Management 16:577-591.

Cheshire, K., Boyero, L., Pearson, R.G. 2005. Food webs in tropical Australian streams: shredders are not scarce. Freshwater Biology 50:748-769.

CONAF. 2011. Catastro de los Recursos Vegetacionales Nativos de Chile, Monitoreo de Cambios y Actualizaciones, Período 1997-2011. Corporación Nacional Forestal, Chile.

Correa-Araneda, F., Gómez-Capponi, F., Díaz, M.E., Ovalle, K., Urrutia, R., FigueroA, R. 2014.Benthic macroinvertebrates community patterns of Mediterranean forested wetlands and their relation with changes in the hydroperiod. Limnetica 33(2):361-374.

Correa-Araneda, F., Rivera, R., Urrutia, J., De Los Ríos, P., Contreras A., Encina-Montoya, F. 2010. Efectos de una zona urbana sobre la comunidad de macroinvertebrados bentónicos de un ecosistema fluvial del sur de Chile. Limnetica 29 (2):183-194.

Correa-Araneda, F., Urrutia J., Figueroa, R. 2011. Estado de conocimiento y principales amenazas de los humedales boscosos de agua dulce de Chile. Revista Chilena de Historia Natural 84:325-340.

Correa-Araneda, F., Urrutia, J., Soto-Mora, Y., Figueroa, R., Hauenstein, E. 2012. Effects of the hydroperiod on the vegetative and community structure of freshwater forested wetlands, Chile. Journal of Freshwater Ecology 1:1-12.

Cortes, R.M.V. 1992. Seasonal pattern of benthic communities along the longitudinal axis of river systems and the influence of abiotic factors on the spatial structure of those communities. Archiv für Hydrobiologie 126:85-103.

Del Valle-Arango, J.I. 2003. Descomposición de la hojarasca fina en bosques pantanosos del Pacífico colombiano. Interiencia 28 (3):148-153. 
Di Castri, F., Hajek, E. 1976. Bioclimatología de Chile. Pontificia Universidad Católica de Chile. Santiago, Chile, 128 pp.

Doll, P., Zhang, J. 2010. Impact of climate change on freshwater ecosystems: a global-scale analysis of ecologically relevant river flow alterations. Hydrology and Earth System Sciences 7:1305-1342.

FAO. 2005. Forests and water. Thematic study for the Global Forest Resources Assessment. Forestly department. Rome, Italy.

Figueroa, R., Suarez, M.L., Andreu, A., Ruiz, V.H., VidalAbarca, M.R. 2009. Caracterización ecológica de humedales de la zona semiárida en Chile Central. Gayana 73 (1):76-94.

Figueroa, R., Valdovinos, C., Araya, E., Parra, O. 2003. Macroinvertebrados bentónicos como indicadores de calidad de agua de ríos del sur de Chile. Revista Chilena de Historia Natural 76:275-285.

Gessner, M.O., Robinson, C.T., Ward, J.V. 1998. Leaf breakdown in streams of an alpine glacial floodplain: dynamics of fungi and nutrients. Journal of the North American Benthological Society 17:403-419.

Graça, M.A.S., CANHoto, C. 2006. Leaf litter processing in low order streams. Limnetica 25(1-2):1-10.

Graça, M.A.S., Cressa, C. 2010. Leaf Quality of Some Tropical and Temperate Tree Species as Food Resource for Stream Shredders. International Reviews of Hydrobiology 95:27-41.

Haapala, A., Muotka, T., Markkola, A. 2001. Breakdown and macroinvertebrate and fungal colonization of alder, birch, and willow leaves in a boreal forest stream. Journal of the North American Benthological Society 20:395-407.

Habit, E., Victoriano, P., Rodríguez-Ruiz, A. 2003. Variaciones espacio-temporales del ensamble de peces de un sistema fluvial de bajo orden del centro-sur de Chile. Revista Chilena de Historia Natural 76:3-14.

Hammer, O., Harper, D., Ryan, P. 2001. PAST: paleontological statistics software for education and data analysis. Paleontología Electrónica 4:1-9. URL:http://palaeoelectronica.org/2001_1/past/issue1_01.htm. Revised: 1 September 2014.

Hauer, F.R., Hill, W.R. 2007. Temperature, light and oxygen. In: Methods in stream ecology (Eds. Hauer, F.R. \& G.A. Lamberti), pp. 103-117. Second edition. Elsevier. Amsterdam, The Netherlands.

Hladyz, S., Tiegs, S.D., Gessner, M.O., Giller, P.S., Rîşnoveanu, G., Preda, E., Nistorescu, M., Schindler, M., Woodward, G. 2010. Leaf-litter breakdown in pasture and deciduous woodland streams: a comparison among three European regions. Freshwater Biology 55:1916-1929.

Little, C., Lara, A., McPhee, J., Urrutia, R. 2009. Revealing the impact of forest exotic plantations on water yield in large scale watersheds in South-Central Chile. Journal of Hydrology 374:162-170.

Lugo, A.E., Brown, S., Brinson, M.M. 1990. Concepts in wetland ecology. In: Ecosystems of the world 15: Forested wetlands. Elsevier. Amsterdam, pp. 53-85.

McIvor, A.L., Möller, I., Spencer, T., Spalding, M. 2012. Reduction of wind and swell waves by mangroves. Natural Coastal Protection Series (1):27.

Molinero, J., Pozo V., Gonzalez, E.1996. Litter breakdown in streams of the Agiiera catchment: influence of dissolved nutrients and land use. Freshwater Biology 36:745-756.
MoritA, R.Y. 1975. Psychrophilic bacteria. Bacteriological Reviews 39:144-167.

Ovalle, K. 2012. Degradación de hojarasca y Estudio de Organismos Macroinvertebrados Bentónicos mediante análisis del tracto intestinal, zona alta del Estero Nonguén, Región del Biobío, Chile. Tesis pregrado. Universidad de Concepción, Chile, pp. 49.

Pizarro, R., Araya, S., Jordan, C., Farías, C., Flores, J.P., Bro, P. 2006. The effects of changes in vegetative cover on river flows in the Purapel river basin of central Chile. Journal of Hydrology 327 (1-2):249-257.

Ramírez, C., Romero, M., Henríquez, O. 1980. Estudios de germinación en semillas de mirtáceas chilenas. Bosque 3(2):106-114.

Ramírez, C., San Martín, C., San Martín, J. 1995. Estructura florística de los bosques pantanosos de Chile sur-central. In: Ecología de los bosques nativos de Chile (Eds. Armesto, J., Villagrán, C., M.K. Arroyo), pp. 215-234. Editorial Universitaria, Santiago, Chile.

Richardson, J.S.C., Shaughnessy, R., Harrison, P.G. 2004. Litter breakdown and invertebrate association with three types of leaves in a temperate rainforest stream. Archiv für Hydrobiologie 159:309-325.

Solada, S.W., Perry, S.A., Perry, W.B. 1996. Leaf litter decomposition and elemental change in three Appalachian mountain streams of different $\mathrm{pH}$. meeting of the northern global change program. In: Proceedings 1995 meeting of the northern global change program (Eds. Hom, J., Birdsey, R. K. O'Brian), pp. 161-164. Department of Agriculture, Forest Service, Northeastern Forest Experiment Station. United State.

Statsoft, Inc. 2004. Statistica (data analysis software system), version 7. URL: http://www.statsoft.com. Revised: 1 September 2014.

Swan, C.M., Palmer, M.A. 2004. Leaf diversity alters litter breakdown in a Piedmont stream. Journal of the North American Benthological Society 23:15-28.

Sylvestre, S., Bailey, R.C. 2005. Ecology of leaf pack macroinvertebrate communities in streams of the Fraser River Basin, British Columbia. Freshwater Biology 50:1094-1104.

Tucker, A.O., Maciarello, M.J., Landrum, L.R. 1993. Volatile Leaf Oils of American Myrtaceae. I. Blepharocalyx cruckshanksii (Hook. \& Arn.) Niedenzu of Chile and B. salicifolius (Humb. Bonpl. \& Kunth) Berg of Argentina. Journal of Essential Oil Research 5(3):333-335.

Vannote, R.L., Minshall, G.W., Cummins, K.W., Sedell, J.R., Cushing, C.E. 1980. The River Continuum Concept. Canadian Journal of Fisheries and Aquatic Science 37:130-137.

Wetzel, R., Likens, G. 1991. Limnological analysis: 1-391. Springer, New York.

Weyers, H.S., Suberkropp, K. 1996. Fungal and bacterial production during the breakdown of yellow poplar leaves in 2 streams. Journal of the North American Benthological Society 15:408-420.

Woodcock, T., Huryn, A. 2005. Leaf litter processing and invertebrate assemblages along a pollution gradient in a Maine (USA) headwater stream. Environmental Pollution 134:363-375. 